\title{
Hvor lenge varer et svangerskap?
}

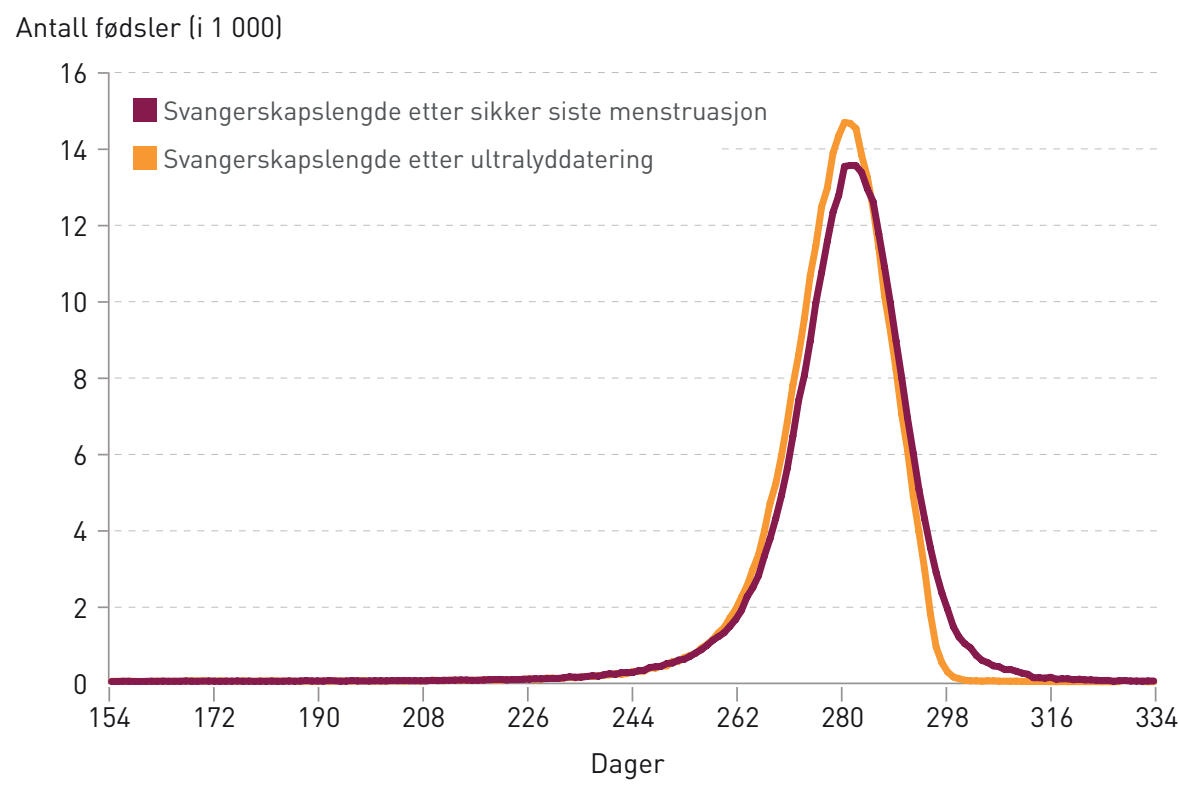

Variasjon i svangerskapslengde i 309749 enkeltsvangerskap etter sikker siste menstruasjon (rød kurve) og spontan fødselsstart i 1999 -2010 (median lengde 283 dager). Gul kurve viser fordelingen for de samme svangerskapene, men basert på ultralyddatering (median estimert svangerskapslengde 281 dager). Data fra Medisinsk fødselsregister

Moses var 40 år i ørkenen, fasten kunne vare i 40 dager og Ali Baba hadde med seg 40 røvere. Tallet 40 har hatt en spesiell plass i religion, tradisjon og kultur. Det er ikke underlig at 40 ukers svangerskap festet seg i bevisstheten etter hvert som behovet for mer eksakt viten avfødte Nägeles regel tidlig på 1800-tallet: svangerskapet varer i 10 menstruasjonssykluser regnet fra siste menstruasjons første dag, dvs. 7 dager $\times 4 \times 10=280$ dager eller 40 uker. I dag definerer også Verdens helseorganisasjon svangerskapets varighet som 40 uker. Men er dette korrekt? Ved nærmere etterprøving viser det seg at et svangerskap i Skandinavia varer i gjennomsnitt 1-3 dager lenger enn 40 uker, regnet fra siste menstruasjons første dag $(1-3)$.

$\AA ̊$ bruke siste menstruasjons første dag til å fastsette svangerskapets varighet er en indirekte metode som forutsetter at befruktningen skjedde på dag 14, med flere muligheter for usikkerhet, bl.a. sykluslengde, ovulasjons- og fertiliseringstidspunkt, tid til implantasjon og kvinnens hukommelse. Rundt halvparten av de gravide har ikke tilstrekkelig regelmessig syklus eller god nok informasjon til å regne ut en pålitelig fosteralder (4). Måling av fosterets størrelse med ultralyd er da en alternativ metode. Under forutsetning av at den biologiske variasjonen er liten i den tidlige delen av svangerskapet, brukes fosterets størrelse til å fastslå alder. Etter denne metoden er svangerskapets lengde i median 40 uker og $0-1$ dag, altså noe kortere enn regnet ut etter siste menstruasjon (2-3).

Nå er det bare rundt $4 \%$ av de gravide som føder på selve termindagen (5). Dette skyldes både metodologisk og biologisk variasjon. Langsomtvoksende fostre har en tendens til å bevirke lengre svangerskap, og storvokste fostre det motsatte (6). Fedre som selv var store ved fødselen, får oftere store sønner etter kortere svangerskap (7). Det finnes altså kjønnsforskjeller og arvelige mekanismer.
Foreldre som selv er født etter overtidig svangerskap, har økt sannsynlighet for å oppleve det samme hos sine barn (8). Totalt sett er variasjonen så betydelig at man regner alle som er født med svangerskapsvarighet 37-42 uker, for å være født til termin. Denne spredningen står i kontrast til den store interesse som medisinsk ekspertise ofte har vist for én enhetlig svangerskapslengde og presis termindato. Befolkningen får lett urimelige forventninger til en termindato som sjelden treffer.

Korrekt fosteralder er avgjørende for behandling og overvåking under svangerskapet: morkakeprøve etter 10. uke, målrettet fosterdiagnostikk i uke 11-13, fostervannsprøve fra fylte 15 uker, rutinemessig ultralydundersøkelse ved 18 uker, levedyktighet og forløsning diskuteres ved fylte 24 uker, lungemodningssprøyte gis før 34 uker, barn født før 37 uker regnes som premature og etter 42 uker er de overtidige. Fosteralder avspeiler fosterutvikling og er en viktig determinant for sykelighet og perinatal død. Derfor bør all tilgjengelig informasjon tas med for å bestemme fosterets alder riktigst mulig. Men det er blitt vanlig bare å bruke rutineultralydundersøkelse, noe som innebærer en forenkling av rutiner og som predikerer tidspunkt for spontan fødsel bedre enn å ta utgangspunkt i selv en sikker og regelmessig siste menstruasjon (5).

Noe av forklaringen på denne treffsikkerheten kan være at sikre menstruasjonsforhold ikke avspeiler konsepsjonstidspunktet godt nok, og at ultralydmålet korrigerer for dette. En annen mulighet er naturlig variasjon knyttet til sammenheng mellom fostervekst og svangerskapslengde. Har mor et foster som vokser mindre enn gjennomsnittet, vil man ved ultralydundersøkelsen etter 18 uker nedjustere alderen tilsvarende og forskyve terminen noe ut i tid. Fysiologisk små fostre har lengre svangerskap (6). Da vil ultralyd- 
undersøkelse treffe bedre enn å ta utgangspunkt i siste menstruasjon. I slike tilfeller gjøres det to feil. Fosteret har fått tildelt for lav alder, og en biologisk variasjon i svangerskapslengde er ikke tatt i betraktning. Dersom dette svangerskapet hadde vart til 42 uker i henhold til termin fastsatt ved ultralydundersøkelse, ville det egentlig ha vært 43 uker. Det er ikke vanskelig å forstå konsekvensene av slikt $i$ et land hvor overtidsdebatten går høyt. Dersom man derimot aksepterte at et foster med langsom vekst og ved sikker informasjon om morens menstruasjon virkelig var 18 uker gammelt, og samtidig godtok at ultralydmetoden bedre predikerer tidspunkt for fødselen, kunne man overfor mor bekrefte alder og samtidig forberede henne på muligheten av et noe lengre svangerskap, dvs. termin ved mer enn 40 uker. Tankegangen vil virke fremmed for mange, fordi forestillingen om en fast svangerskapslengde for alle er så innprentet. En slik måte å vurdere normale svangerskap på gir imidlertid også muligheter til å se med nye øyne på svangerskapsutfall etter 42 uker.

Med andre ord: svangerskapets varighet er underlagt variasjon på linje med all annen biologisk variasjon. Ved å verdsette denne variasjonen og utnytte den i svangerskapsomsorgen, er vi mer i pakt med biologien. Men da må vi også skille mellom fastsettelse av fosteralder, som kan gjøres på flere måter, og terminbestemmelse, der en ultralydundersøkelse kan angi en sannsynlig tid for nedkomst.

\section{Torvid Kiserud}

torvid.kiserud@kk.uib.no

Torvid Kiserud (f. 1944) er professor ved Universitetet i Bergen og overlege ved Kvinneklinikken, Haukeland universitetssykehus. Han leder Klinisk fosterfysiologisk forskningsgruppe, Nasjonalt behandlingssenter for gynekologiske fistler og Global reproduktiv forskningsklynge. Ingen oppgitte interessekonflikter.

\section{Litteratur}

1. Bergsjø P. Denman DW III, Hoffman HJ et al. Duration of human singleton pregnancy. A population-based study. Acta Obstet Gynecol Scand 1990; 69: 197-207.

2. Tunon K, Eik-Nes SH, Grøttum P. A comparison between ultrasound and a reliable last menstrual period as predictors of the day of delivery in 15,000 examinations. Ultrasound Obstet Gynecol 1996; 8: 178-85

3. Nguyen TH, Larsen T, Engholm $G$ et al. Evaluation of ultrasound-estimated date of delivery in 17,450 spontaneous singleton births: do we need to modify Naegele's rule? Ultrasound Obstet Gynecol 1999; 14: 23-8.

4. Geirsson RT, Busby-Earle RM. Certain dates may not provide a reliable estimate of gestational age. BJOG 1991: 98: 108-9

5. Mongelli M, Wilcox M, Gardosi J. Estimating the date of confinement: ultrasonographic biometry versus certain menstrual dates. Am J Obstet Gynecol 1996 174: 278-81.

6. Johnsen SL, Wilsgaard T, Rasmussen $\mathrm{S}$ et al. Fetal size in the second trimester is associated with the duration of pregnancy, small fetuses having longer pregnancies. BMC Pregnancy Childbirth 2008; 8: 25.

7. Lie RT, Wilcox AJ, Skjaerven R. Maternal and paternal influences on length of pregnancy. Obstet Gynecol 2006; 107: 880-5.

8. Morken N-H, Melve KK, Skjaerven R. Recurrence of prolonged and post-term gestational age across generations: maternal and paternal contribution. BJOG 2011; 16: $30-5$. 